\title{
THE INTERNATIONAL CONGRESS OF MATHEMATICIANS
}

\author{
CAMBRIDGE, MASSACHUSETTS, U.S.A., SEPTEMBER 4-12, 1940
}

On invitation by the American Mathematical Society, an International Congress of Mathematicians will be held in Cambridge, Massachusetts, in 1940.

Former Congresses. In connection with the World's Columbian Exposition in Chicago in 1893 there was an International Congress of Mathematicians. The first congress in Europe was held at Zürich in 1897 , and the most recent one met in Oslo in 1936. In the interim, with a few omissions necessitated by the World War, there have been sessions about once every four years. These have all been in Europe except for that of 1924, which was held at the University of Toronto with the financial support of the province and the Dominion.

At recent congresses, the number of countries represented has been about 40 , the number of members about 600 , and the number of short papers submitted about 250 .

Time and place. The dates of the Congress have been fixed as September 4-12, 1940. The Society will omit its usual summer meeting in 1940. Harvard University and the Massachusetts Institute of Technology will be the local hosts of the Congress. Some neighboring institutions will join in the hospitality, but all institutions in the United States and Canada are invited to consider themselves as participants. Mathematicians so desiring will be housed in the Harvard University dormitories at modest rates, and meals will be served at cost in the University dining rooms. There will be accommodations for members of families, special provision being made for the care of children. Those who prefer to live in hotels can be comfortably provided for in Cambridge or Boston. It is expected that the Society will be able to furnish room and board without charge for a considerable number of foreign guests during the week that they are in Cambridge. In connection with the Harvard Tercentenary, the American Mathematical Society and the Mathematical Association of America met in Cambridge in September, 1936. There is no need of assuring any of the 800 people who were present then that excellent arrangements will be made for the Congress.

Organization. Plans for the scientific features of the Congress are well under way. Following precedent, there will be a score of invited addresses, each of an hour's length, and sectional meetings for the presentation of short papers.

An innovation will be conferences, somewhat after the pattern of 
recent international gatherings in Moscow for Topology and in Zürich for Probability. Each conference will be devoted to some field in which a vigorous advance has recently been made or is currently in progress. The purpose will be the exchange of information and opinion by specialists in the field, and the dissemination of new and important results among the mathematical public at large. This will be accomplished by a coördinated program of formal lectures and informal open discussion. Among the conferences will be one on Algebra, with Professor A. A. Albert as chairman, one on the Theory of Measure, Probability, and Allied Topics, with Professor Norbert Wiener as chairman, one on Mathematical Logic with Professor H. B. Curry as chairman, and one on Topology with Professor Solomon Lefschetz as chairman.

Six sections are tentatively planned for the presentation of papers: (I) Algebra and Theory of Numbers; (II) Analysis; (III) Geometry and Topology; (IV) Probability, Statistics, Actuarial Science, Economics; (V) Mathematical Physics and Applied Mathematics; (VI) Logic, Philosophy, History, Didactics. The International Commission on the Teaching of Mathematics proposes to have a session in connection with the Congress.

These short papers will be preferably in one of the official languages of the Congress (English, French, German, and Italian), and will not exceed ten minutes in length.

Social features, excursions. There will be many interesting entertainment features provided - reception, garden party, symphony concert, and banquet. In addition there will be a number of automobile excursions, and it is hoped that American mathematicians will be able to assist in the entertainment by putting their automobiles at the disposal of the Entertainment Committee for trips to be made out of Cambridge.

Every effort will be made to facilitate the travel at reasonable cost of foreign participants while in the United States. Previous to the Congress, opportunity will be given them to see New York City under the guidance of some mathematician. It is expected that an international exposition will be in progress at that time in the city. Excursions to Washington, Niagara Falls, and other places will be arranged if there is demand.

Membership in the Congress. Membership in the Congress will be open to all persons, whether they are able to be present in person or not. For regular members of the Congress, the fee is $\$ 10.00$; these persons will receive the Proceedings of the Congress. Persons not participating in the scientific deliberations may become associate members, for 
whom the fee is $\$ 5.00$; they will not present papers nor receive the Proceedings but will be entitled to many of the other privileges of membership.

Financial support. Besides the support from Harvard University, Massachusetts Institute of Technology, and other institutions in the neighborhood, generous subventions have been subscribed for the Congress by the Carnegie Corporation, the Institute for Advanced Study, the National Research Council, and the Rockefeller Foundation.

Information. Detailed information will be sent in due course to all members of the American Mathematical Society. Others interested in receiving information may file their names in the Office of the Society, and such persons will receive from time to time information regarding the program and arrangements.

Communications should be addressed to the American Mathematical Society, 531 West 116th Street, New York City, U.S.A.

The Organizing Committee 